WellBeing International

WBI Studies Repository

$12-2015$

\title{
Influence of Rock-Pool Characteristics on the Distribution and Abundance of Inter-Tidal Fishes
}

\author{
Gemma E. White \\ Macquarie University \\ Grant C. Hose \\ Macquarie University \\ Culum Brown \\ Macquarie University
}

Follow this and additional works at: https://www.wellbeingintlstudiesrepository.org/acwp_ehlm

Part of the Animal Studies Commons, Environmental Studies Commons, and the Population Biology Commons

\section{Recommended Citation}

White, G. E., Hose, G. C., \& Brown, C. (2015). Influence of rock-pool characteristics on the distribution and abundance of inter-tidal fishes. Marine Ecology, 36(4), 1332-1344.

This material is brought to you for free and open access by WellBeing International. It has been accepted for inclusion by an authorized administrator of the WBI Studies Repository. For more information, please contact wbisr-info@wellbeingintl.org.

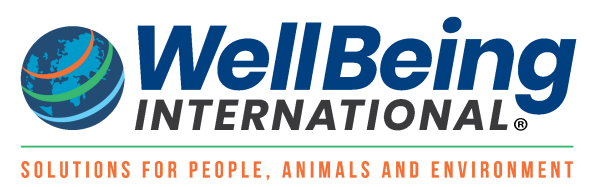




\title{
Influence of rock-pool characteristics on the distribution and abundance of inter-tidal fishes
}

\author{
Gemma E. White, Grant C. Hose, and Culum Brown \\ Macquarie University
}

\section{KEYWORDS}

assemblages, habitat complexity, inter-tidal fish, refuges, rock-pool characteristics

\begin{abstract}
Rock pools can be found in inter-tidal marine environments worldwide; however, there have been few studies exploring what drives their, fish species composition, especially in Australia. The rock-pool environment is highly dynamic and offers a unique natural laboratory to study the habitat choices, physiological limitations and adaptations of inter-tidal fish species. In this study rock pools of the Sydney region were sampled to determine how the physical (volume, depth, rock cover and vertical position) and biological (algal cover and predator presence) parameters of pools influence fish distribution and abundance. A total of 27 fish species representing 14 families was observed in tide pools at the four study locations. The five most abundant species were Bathygobius cocosensis, Centropogon australis, Enneapterygius atrogulare, Lepidoblennius haplodactylus and Microcanthus strigatus, which together represented $71 \%$ of the total number of fish recorded. Larger rock pools containing more algal and rock ledge cover hosted a larger and more diverse population of fish. Furthermore, certain species were only found in pools with specific characteristics, such as the presence of loose shells, a variety algae or rock cover, suggesting a high degree of habitat specificity. By contrast, some species were ubiquitous and thus can likely tolerate a wide variety of physical conditions.
\end{abstract}

\section{Introduction}

Community ecology is driven by the need to describe the patterns associated with the composition, abundance and distribution of species assemblages and to develop an understanding of the processes that cause these patterns to occur (Begon et al. 1986; Diamond \& Case 1986). These processes include physical (i.e. topography), chemical (i.e. variations in oxygen, salinity, temperature) and biological (i.e. predation, competition, habitat selection) interactions. The role of community ecologists is to understand when and how these processes regulate community organization, so that they are able to correctly interpret why assemblages differ among locations (Metaxas \& Scheibling 1993) and make predictions about locations that have yet to be sampled.

The inter-tidal zone presents an ideal model system for studies focusing on community ecology, as it exhibits variation in multiple quantitative environmental factors. Inter-tidal habitats can vary from sandy beaches to mudflats, coral reefs, steep bluffs and rocky shores, all of which support differing species assemblages. Inter-tidal fish communities, in particular, are known to differ in their composition across 
continents, with latitude, among regions and within single locations (Gibson \& Yoshiyama 1999). The distribution of species across continents and with latitude can be explained by dispersal ability and geographic patchiness, while community patterns at regional and local scales are largely driven by the physical and chemical factors of the environment (Gibson \& Yoshiyama 1999; Cox et al. 2011).

Rock pools are commonly occurring features on the richly structured and sloping rocky shores of the inter-tidal zone. These holes and depressions retain water at low tide, acting as refuges for many intertidal organisms (Zander et al. 1999). Rock pools are extremely productive microhabitats that contain a diverse range of plant, invertebrate and fish life; however, they are isolated and patchily distributed along the shore and are highly variable in time (i.e. tidal, seasonal and diurnal) and space (from geographic to local scales) (Martins et al. 2007; Firth et al. 2013). As a result, many fish species have developed a range of different behavioral, physiologic and morphologic adaptations that allow them to tolerate the drastic changes in the physical environment that occur within rock pools during low tides (Zander et al. 1999). Almost all coastal fish species may, at some point or another in their lifetime, utilize rock pools in their search for food, as refuges from predators or as areas for growth, development and reproduction (Horn et al. 1999) and thus rock pools represent a key habitat for underpinning coastal fish species diversity.

Rock-pool fish assemblages are composed of three main groups of fishes: residents, secondary residents and transients. Each group is classified according to their behaviors and the proportion of their life history that they spend occupying rock pools (Mahon \& Mahon 1994; Griffiths 2003), which is likely reflective of their ability to tolerate the stresses associated with inter-tidal life. Residents spend the majority of their lifetime in rock pools and are physiologically, morphologically and behaviorally adapted for inter-tidal life (White \& Brown 2013). Secondary residents opportunistically utilize rock pools during the juvenile stage of development (i.e. as nurseries), after which an ontogenetic shift to off-shore habitats occurs as they grow into adults (Bell et al. 1980; White \& Brown 2013). This may account for the relatively few morphologic adaptations that secondary residents have for inter-tidal life. Transients are only present in rock pools on certain occasions or by accident, and are most often species that entered pools at high tide and became trapped at low tide (Griffiths 2003).

The structure and composition of these rock-pool assemblages is further regulated by within-pool biological factors, such as the availability of shelter (Gibson 1982), quantity of algal turf versus algal plants (Jones 1984), presence of preferred food resources (Gibson 1974) and presence of predators (Paine 1974), combined with physical factors, such as pool depth, volume and vertical position on the rock platform (Macieira \& Joyeux 2011), and physicochemical factors, such as temperature, pH, salinity and oxygen content (Horn et al. 1999).

Like many terrestrial ecosystems, fish assemblage structure and species composition vary depending on the complexity of the environment (Horn et al. 1999). According to Griffiths et al. (2006), there are two main types of habitat accessible to fishes living in rook pools, each of which can differ greatly in its structural complexity. The fronds of algal plants produce floating cover in the water column, and are most often utilized by midwater and pelagic species. Alternatively, the structural complexity of the pool substratum with its crevices, various sized rocks, shells and sand under which fish can shelter, is more likely to be important to benthic species (Davis 2000). Structural complexity in a habitat generally can have direct affects on fish abundance and assemblage structure by supplying shelter for competitors, predators and prey, and permitting larger numbers of species to co-exist via the spatial portioning of limited resources (Behrents 1987; Hixon \& Beets 1993). Furthermore, the utilization of refuges by rockpool fish is likely to increase in necessity as high tide advances and brings with it subtidal predators (Silberschneider \& Booth 2001). Habitat complexity can also provide fish with shelter from physical stresses encountered in tidally isolated rock pools (i.e. wave action, temperature and salinity). For 
example, the temperature in boulder and algae habitats may be cooler during summer and warmer in winter than the temperature outside the refuge (Gibson 1982). Rock pools supporting algal plant cover have greater species diversity and abundance of individuals (Marsh et al. 1978), and contain different species as opposed to rock pools that have a barren substratum (Bennett \& Griffiths 1984).

The physicochemical factors (i.e. temperature, $\mathrm{pH}$, salinity, dissolved oxygen and carbon dioxide) present within rock pools are highly dependent on the amount of time for which they are isolated from the sea during low tide, which in turn is related to their vertical location on the rock platform and their volume (Macieira \& Joyeux 2011). Pools higher up in the inter-tidal zone will be exposed to external conditions for longer than those further down. Thus, isolation and evaporation is considered to be one of the major factors controlling the composition and distribution of fish assemblages (Gibson 1974). Within rock pools, temperatures can rise by greater than $15^{\circ} \mathrm{C}$, salinity can increase by $3 \mathrm{ppt}$ and oxygen levels can reach hypoxic conditions in the space of a few hours (Congleton 1980; Metaxas \& Scheibling 1993; Jensen \& Muller-Parker 1994). In Hong Kong, during the summer season, rock pools have been shown to reach temperatures of up to $40{ }^{\circ} \mathrm{C}$ (Williams \& Morritt 1995), salinities of $40 \&$ and dissolved oxygen levels as low as $0.1 \mathrm{mg}^{-1}{ }^{-1}$ (Firth \& Williams 2009). Therefore, the degree to which a species is able to occupy and survive in the upper inter-tidal zone is determined by its capacity to withstand the drastic changes in temperature, salinity and oxygen levels (Gibson 1982; Zander et al. 1999). For example, Kemp (2009) found that resident species were able to tolerate higher temperatures and salinities and lower oxygen levels than were secondary residents; this may in turn allow the former species to more effectively occupy rock pools higher up in the inter-tidal zone.

However, physical features of the pool such as water depth and volume also drive assemblage structure and composition within rock pools via other mechanisms (Mahon \& Mahon 1994; Macieira \& Joyeux 2011). For example, large, deep rock pools generally have greater fish numbers and support more midwater/pelagic species that are only able to tolerate a narrow range of environmental conditions (Mahon \& Mahon 1994; Gibson \& Yoshiyama 1999). The volume and depth of a rock pool also interact with the physiochemical characteristics of the pool. For example, pools of large volume are less prone to large fluctuations in salinity and temperature (Firth \& Williams 2009). Thus, fish distribution within the inter-tidal zone can be somewhat 'azonal' as the presence of individual species depends also on the characteristics of the rock pool itself rather than just its vertical position on the rocky shore (Zander et al. 1999).

Many studies have explored how one or two key physical or biological features regulate species distribution and abundance within rock pools such as: defaunation (Lardner et al. 1993), vertical position (Griffiths et al. 2003), structural complexity and volume (Griffiths et al. 2006; Cunha et al. 2008), and water chemistry and volume (Kemp 2009; Tsering et al. 2012). Very few, however, have tried to determine how all of these features interact with one another to regulate overall assemblage structure and species composition (Cox et al. 2011; Macieira \& Joyeux 2011).

Despite the fact that rock pools can be found in intertidal marine environments worldwide, there have been few studies exploring what physiological and biological factors drive their species composition, particularly in Australia (Wilson 1989; Lardner et al. 1993; Underwood \& Skilleter 1996; Silberschneider \& Booth 2001; Griffiths et al. 2003; Griffiths et al. 2006). This needs to be addressed directly because the preservation of marine biodiversity is gaining greater worldwide support. The main aim of this study was, therefore, to determine the major physical and biological factors influencing the abundance of rock-pool fishes. In particular, we attempted to: (i) evaluate the importance of within-pool rock shelter, algal cover, substrate type (rock or sand), rock-pool depth and volume, and predator presence in controlling fish assemblage structure; and (ii) determine which of these variables had the greatest influence on species 
distribution and abundance. We hypothesized that the main factor determining the presence of fishes in particular rock-pool habitats will be the presence of within-pool cover/shelter

\section{Material and Methods}

\section{Study sites and species}

Field studies were undertaken at a number of rock platforms (Dee Why, Harbord Headland, Rocky Point at Balmoral Beach and Georges Head near Chowder Bay) in the Sydney region, New South Wales, Australia. These rock platforms were chosen for their abundance of rock pools and their relative ease of access.

A total of 48 permanent tide pools was sampled at the four study sites between August and December. These pools were chosen because they were small enough to be sampled in their entirety in 1 day, large enough to contain a population of resident fish and existed within a tidal range that could be sampled during most low tides $(\leq 0.0-0.6 \mathrm{~m}$ ). Detailed surveys of the study pools were conducted before any fish collections were undertaken to determine which pool characteristics were linked to fish diversity and abundance. The vertical position of pools on the rock platform was recorded as low, mid or high depending on their distance from the water at the time of peak low tide (Cox et al. 2011). Rock pools closest to the water's edge $(0-5 \mathrm{~m})$ were classified as low, while rock pools located on the upper edge of the inter-tidal zone nearest to terrestrial vegetation or a vertical rock face but still submerged at high tide (10-15 m) were classified as high, and any rock pools located between low or high pools (5-10 m) were classified as mid. Rock-pool characteristics were measured with transect tape as follows: length (I), maximum distance across the surface of the rock pool; width (w), the distance perpendicular to the length axis at the midpoint of the rock pool; radius ( $r$ ), length of rock pool divided by two; and depth (d), measurement of deepest point within the rock pool. These measurements were then used to produce an estimate of pool volume by using the formula for a 3D shape that was most closely related to the shape of the pool (i.e. cylinder $=\pi r^{2} d$, half ellipsoid $=0.083 \pi \mathrm{lwd}$ and cube $=\mathrm{lwd}$ ). Percentage cover estimates of rock-pool habitat were determined by using a $20 \times 30 \mathrm{~cm}$ quadrat divided into $245 \times 5 \mathrm{~cm}$ squares. Up to 30 random points were selected within each pool for sampling with the quadrat (i.e. total number of quadrats deployed in each pool was determined by pool size). The substrate type found under each $5 \times 5$ $\mathrm{cm}$ square within the quadrat was quantified as bare rock, rock ledge, algae, pebbles, shells or sand (Silberschneider \& Booth 2001). The number of different algae species present and the presence of predators were also documented for each rock pool, by recording sightings of three potential predators, octopus (Octopus tetricus and Hapalochaena maculosa), eels (Gymnothorax prasinus) and shore crabs (Cyclograpsus audouinii, Leptograpsus variegates, Plagusia glabra and Plagusia chabrus) in the rock pool. Each pool was given a score out of three, 0 being the lowest (i.e. no predators present) and 3 being the highest predator rating (i.e. three types of predator present). Shore crabs may seem unlikely predators; however, these animals are opportunistic omnivores and have been observed attempting to eat small fishes (G. E. White, personal observation).

\section{Fish census collection}

Fish diversity and abundance was determined for each rock pool by collecting all individuals within the pool at low tide using small, hand-held nets and temporarily transferring them to a tank containing $4 \mathrm{I}$ fresh aerated seawater. Each individual was counted, identified, categorized by residency status (resident, secondary residents, transients) and measured (total length). After a secondary check for any remaining fish within the rock pool, all fish were then returned alive to the rock pool in which they were captured, unless a species could not be identified in situ, in which case one sample specimen was retained for later identification. In larger pools (surface area $>6 \mathrm{~m}^{2}$ ) where capture of all fish specimens 
was not possible within one low tide cycle, a visual census was used to determine overall fish numbers. This involved four observers making a slow lap of the circumference of the pool, for a maximum of 30 min, identifying species, estimating their total length and performing fish counts, of which the mean of the four observations was taken. A hand net was occasionally used during visual census to encourage fish hiding under rock ledges and within algae to make themselves visible for counting.

\section{Statistical analysis}

Rock-pool composition was compared among the four sample locations using non-metric multidimensional scaling (nMDS). Data were square-root transformed and a similarity matrix was constructed using the Bray-Curtis similarity coefficient (Clarke \& Green 1988). Analysis of similarity (ANOSIM) was used to compare assemblages among locations. Analysis of variance (ANOVA) was used to compare the mean species richness and total abundance among sampling locations and rock pool vertical positions. As there was no observed location effects on species richness or abundance (see Results), data from all four locations were pooled for further analysis.

To determine if any of the physical features of the rock pool were related to observed fish assemblage patterns, a distance-based linear model (DISTLM) was utilized in combination with a distance-based redundancy analysis (dbRDA) for visualizing results (Anderson et al. 2008). Data were square-root transformed and analysed using the Bray-Curtis similarity index. Draftsman plots were used to identify correlations between rock pool characteristics; variables that were correlated $>0.8$ were not included in any further analyses. Step-wise DISTLM was used to identify which of the rock-pool characteristics accounted for a significant part of the variation in fish assemblage composition, while also assessing the relationship of all variables individually. The unique (partial) contribution of each significant variable to the final model (generated via the step-wise DISTLM analysis) was determined by evaluating the changes in variation explained by the model with the inclusion of that variable once all other significant variables had already been incorporated.

The relationship between rock-pool characteristics and the presence or absence of individual species was analysed using stepwise multiple logistic regressions. The abundance of common fish species occupying pools that differ in vertical position (high, mid and low) and the presence of predators (rated 1-3) was compared using ANOVA. Regressions and ANOVAs were only conducted for species that occurred in more than three pools and were represented by more than 10 individuals.

All analyses were performed using PRIMER (v. 6.1.11; Primer-E Ltd, UK), PERMANOVA+ (v. 1.0.1; Primer-E Ltd, Plymouth, UK) and StatView (v. 5.0.1; SAS Institute Inc., Cary, NC, USA 1988). The significance level (a) for all analyses was 0.05 .

\section{Results}

\section{Comparison of study locations}

There was no significant difference in the fish assemblages among locations (ANOSIM, $P=0.093$ ), which was evident by the lack of obvious site clumping, in the nMDS plot (Fig. 1). Furthermore, there were no significant differences in average species richness and total abundance among the four study locations $\left(F_{3,43}=0.845, P=0.477\right.$ and $F_{3,43}=1.935, P=0.138$, respectively $)$. This indicates that structural complexity of the rock pool, rather than location, was responsible for the variation in number of fish species present and total fish abundance within pools. As there was no observed location affects on species richness or abundance, data from all four locations were pooled for further analysis. 


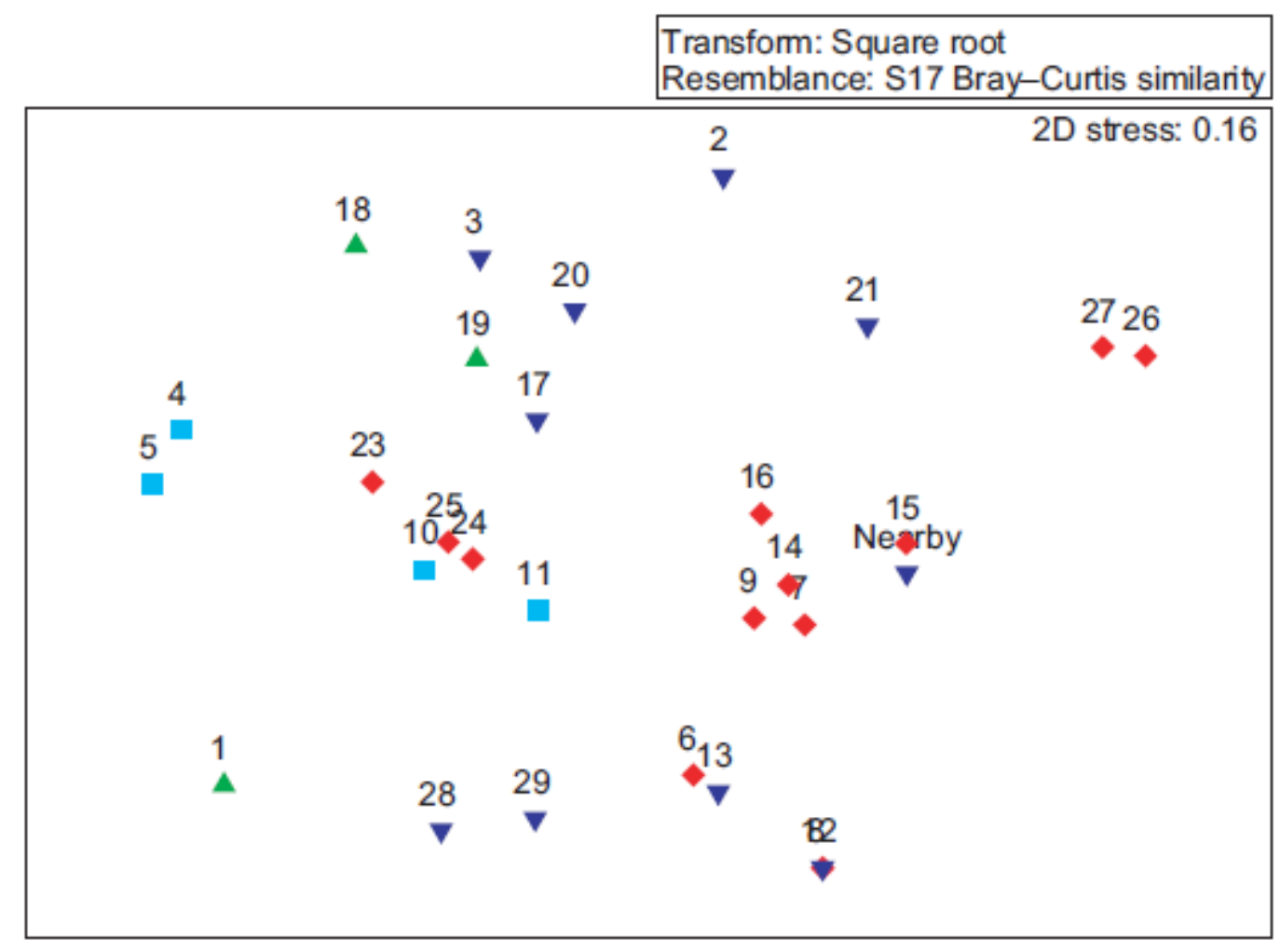

Fig. 1. Non-metric multidimensional scaling (nMDS) ordination plot of assemblages of rockpool fish in each location: ( $\triangle$ ) Balmoral beach, $(\nabla)$ Chowder Bay, ( $\nabla)$ Dee Why beach, and $(\diamond)$ Freshwater beach. Sites which have similar fish abundances are positioned closer to one another. Numbers refer to rock pool identification numbers.

Vertical position of rock pools did not affect species richness and total abundance $\left(F_{2,45}=0.513, P=\right.$ 0.602 and $F_{2,45}=0.966, P=0.389$, respectively). However, there was variation at the species level. Resident species Bathygobius cocosensis, Enneapterygius atrogulare and Lepidoblennius haplodactylus, and secondary residents Centropogon australis and Microcanthus strigatus were found in rock pools at all vertical positions (Fig. 2). By contrast, residents Heteroclinus fasciatus and Heteroclinus whiteleggii were only found in rock pools at high and mid positions on the rock platform. Finally, residents Parablennius intermedius and Bathygobius krefftii, secondary residents Abudefduf vaigiensis and Terapon jarbua, and transients Parupeneus spilurus, Ambassis marianus and Atherinomorus lacunosus were only found in rock pools at mid and low vertical positions (Fig. 2).

Influences of rock pool characteristics on fish assemblages

Forty-eight permanent tide pools, with varied sizes (from $20 \mathrm{~cm}^{2}$ to $\sim 8 \mathrm{~m}^{2}$ ) and low tide water heights ranging from 8 to $58 \mathrm{~cm}$ deep, were sampled during this study. Rock-pool substrates were predominantly sandstone, with some pools containing rocks of various sizes (pebbles-boulders), sand and/or shell grit, overhanging rock ledges and small caves. Algal cover varied from $0 \%$ to $80 \%$ and algal species diversity was quite high (some pools containing up to eight species). 
The structure of rock-pool fish assemblages was significantly related $(P<0.05)$ to the depth and volume of the pool, and to the cover of shells, algae and rock ledges when tested alone (Table 1). The relationship between fish assemblage composition and cover of algae was borderline significant $(P=$ 0.051, Table 1).

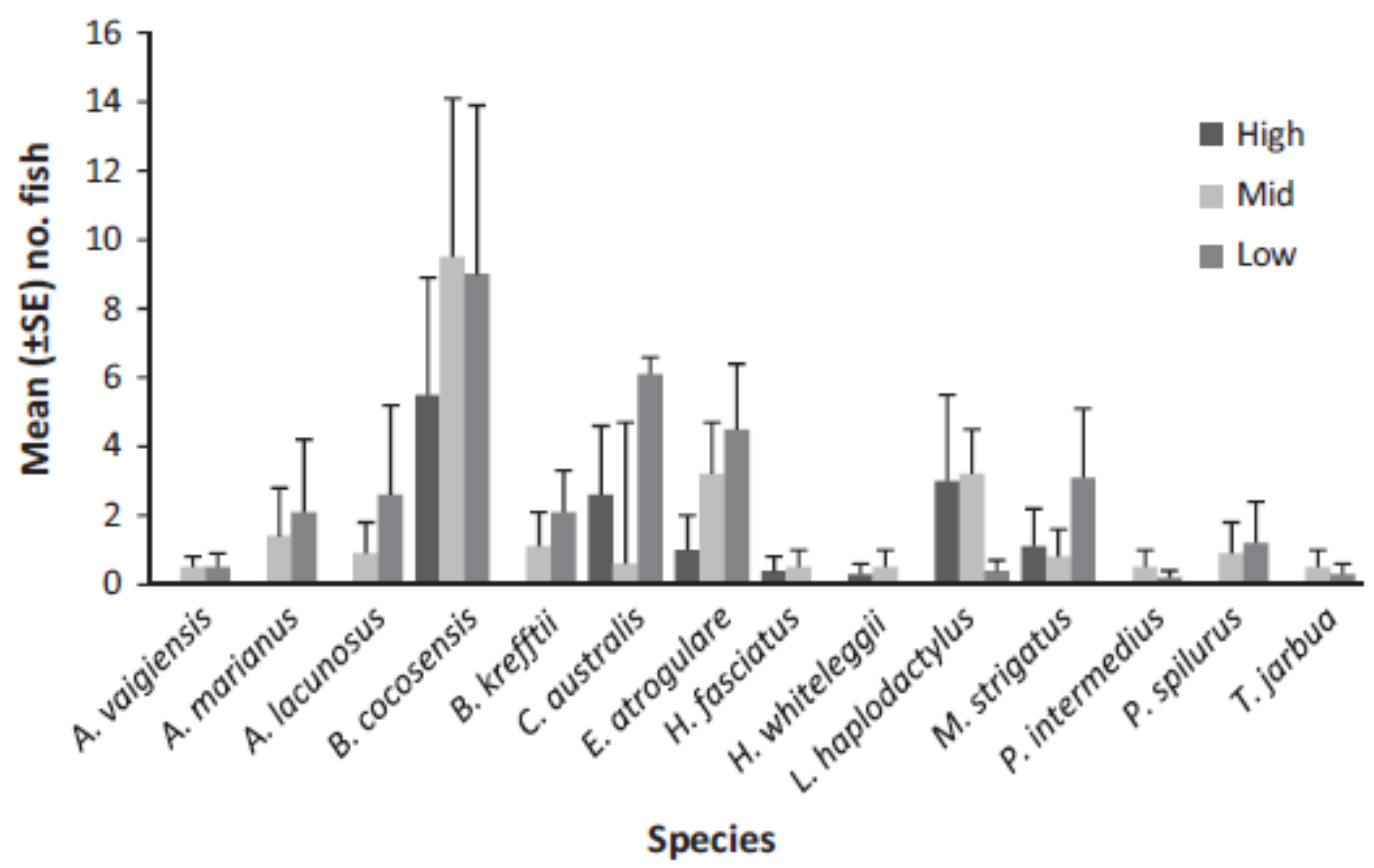

Fig. 2. Mean (SE士) number of fish observed in rock pools at each vertical position (High, Mid and Low) on the rock platform.

The stepwise DISTLM indicated that rock-pool fish assemblages responded significantly to five environmental variables within the rock pools. These were, in order of most influential: pool depth, \% shells, \% pebbles, \% algae cover and \% rock ledges (Table 1 ). The addition of the remaining variables (rock pool volume, \% bare rock and \% sand) to the model did not significantly increase the variance explained. Of the significant variables, the percentage cover of shells made the greatest unique contribution (10\%) to explaining the variability in the assemblage structure and the proportion of rock ledges the least (Table 1). The dbRDA accounted for $32.5 \%$ of the total variation in the data, of which $81.3 \%$ could be explained by the first two axes (Fig. 3). There was a strong gradient along the first axis, grouping rock pools without fish to left and those with fish to the right. Pools without fish had substrata composed predominately of sand and bare rock. Rock pools with large numbers of fish tended to be quite deep, with many rock ledges and algal cover (Fig. 3). There were a few pools with large numbers of fish that were somewhat shallower and were dominated by large amounts of shells and pebbles. These sites grouped together towards the top right of the ordination plot (Fig. 3).

Rock-pool characteristics determine species composition

A total of 1228 fish from 27 species and representing 14 families was observed within the four study locations (Table 2). The most common families in terms of species numbers were Gobiidae (five species), Tripterygiidae, Atherinidae, Clinidae, Blenniidae, Terapontidae and Tetraodontidae (two species each). 
The five most abundant species were Bathygobius cocosensis, Centropogon australis, Enneapterygius atrogulare, Lepidoblennius haplodactylus and Microcanthus strigatus, which together represented $71 \%$ of the total number of fish recorded during this study. The fish assemblage structure was composed predominantly of residents ( $48 \%$ of the total species and $60 \%$ of the total numbers). The remainder of the species was evenly divided between secondary residents and transients. However, overall fish numbers were greater for secondary residents (30\%) than transients (10\%).

Although a total of 27 inter-tidal species was observed in rock pools, regression analysis was restricted to the 13 species for which there were sufficient data. The presence of Bathygobius cocosensis and Parupeneus spilurus was significantly correlated with two rock-pool characteristics; these fish were most likely to be found in pools with a large volume and a greater \% of rock ledges (Table 3). Enneapterygius atrogulare presence was correlated with pools with large numbers of algae species and large volumes. The presence of Ambassis marianus correlated with deep pools with large volumes. Centropogon australis, Terapon jarbua and Atherinomorus lacunosus were significantly more likely to be found in rock pools with large volumes (Table 3). Lepidoblennius haplodactylus and Parablennius intermedius presence was correlated with pools with large numbers of algae species. The presence of Microcanthus strigatus, Heteroclinus fasciatus and Heteroclinus whiteleggii was determined by pool depth. Bathygobius krefftii was significantly more likely to be found in rock pools with a greater $\%$ of shells (Table 3 ).

Table 1. Relationship between rock-pool characteristics and fish abundances. Variables are listed in order of addition in the forward selection model. The partial $R^{2}$ and corresponding $P$-values reflect the unique proportion of variation in the model accounted for by that variable once others in the list had already been fitted.

\begin{tabular}{|c|c|c|c|c|c|c|c|}
\hline \multirow[b]{2}{*}{ Characteristic } & \multicolumn{3}{|l|}{ marginal test } & \multicolumn{4}{|l|}{ sequential test } \\
\hline & individual $\mathbf{R}^{2}$ & pseudo-F & $\mathbf{P}$ & cumulative $\mathrm{R}^{2}$ & individual $\mathbf{R}^{2}$ & pseudo-F & $\mathbf{P}$ \\
\hline depth (cm) & 0.097 & 4.811 & 0.012 & 0.097 & 0.079 & 4.811 & 0.003 \\
\hline shells \% & 0.080 & 4.505 & 0.007 & 0.185 & 0.100 & 4.778 & 0.005 \\
\hline pebbles $\%$ & 0.054 & 3.979 & 0.041 & 0.252 & 0.065 & 3.865 & 0.016 \\
\hline algae $\%$ & 0.051 & 2.400 & 0.051 & 0.320 & 0.081 & 4.195 & 0.005 \\
\hline rock ledges \% & 0.081 & 1.256 & 0.01 & 0.370 & 0.050 & 3.259 & 0.027 \\
\hline volume (I) & 0.091 & 2.574 & 0.001 & 0.400 & 0.030 & 1.972 & 0.119 \\
\hline bare rock $\%$ & 0.027 & 3.907 & 0.246 & 0.407 & 0.008 & 0.497 & 0.736 \\
\hline sand $\%$ & 0.045 & 2.132 & 0.089 & 0.412 & 0.005 & 0.308 & 0.825 \\
\hline
\end{tabular}

The presence of predators such as octopus, shore crabs or eels in rock pools only correlated with the presence of three species. Bathygobius cocosensis was significantly more likely to be present in rock pools with only one predator type present $\left(F_{2,45}=4.035, P=0.024\right)$. By contrast, Enneapterygius atrogulare and Lepidoblennius haplodactylus were significantly more likely to be present in rock pools with two types of predator present $\left(F_{2,45}=25.16, P<0.0001 ; F 2,45=10.68, P=0.0002\right.$, respectively).

\section{Discussion}

Influences of rock-pool characteristics on fish assemblages

Rock pools with greater physical complexity supported a higher abundance and diversity of fish species than less complex rock pools. Greater habitat complexity provides a diverse array of micro-niches for a greater variety of species to exploit. This represents a general finding in ecology, as many studies have reported similar results in a range of animal taxa from both terrestrial and aquatic environments, such as 
birds (Telleria \& Carrascal 1994), mammals (Williams et al. 2002), lizards (Pianka 1973), fish (Gratewicke \& Speight 2005), insects (Davidowitz \& Rosenzweig 1998) and gastropods (Beck 2000).

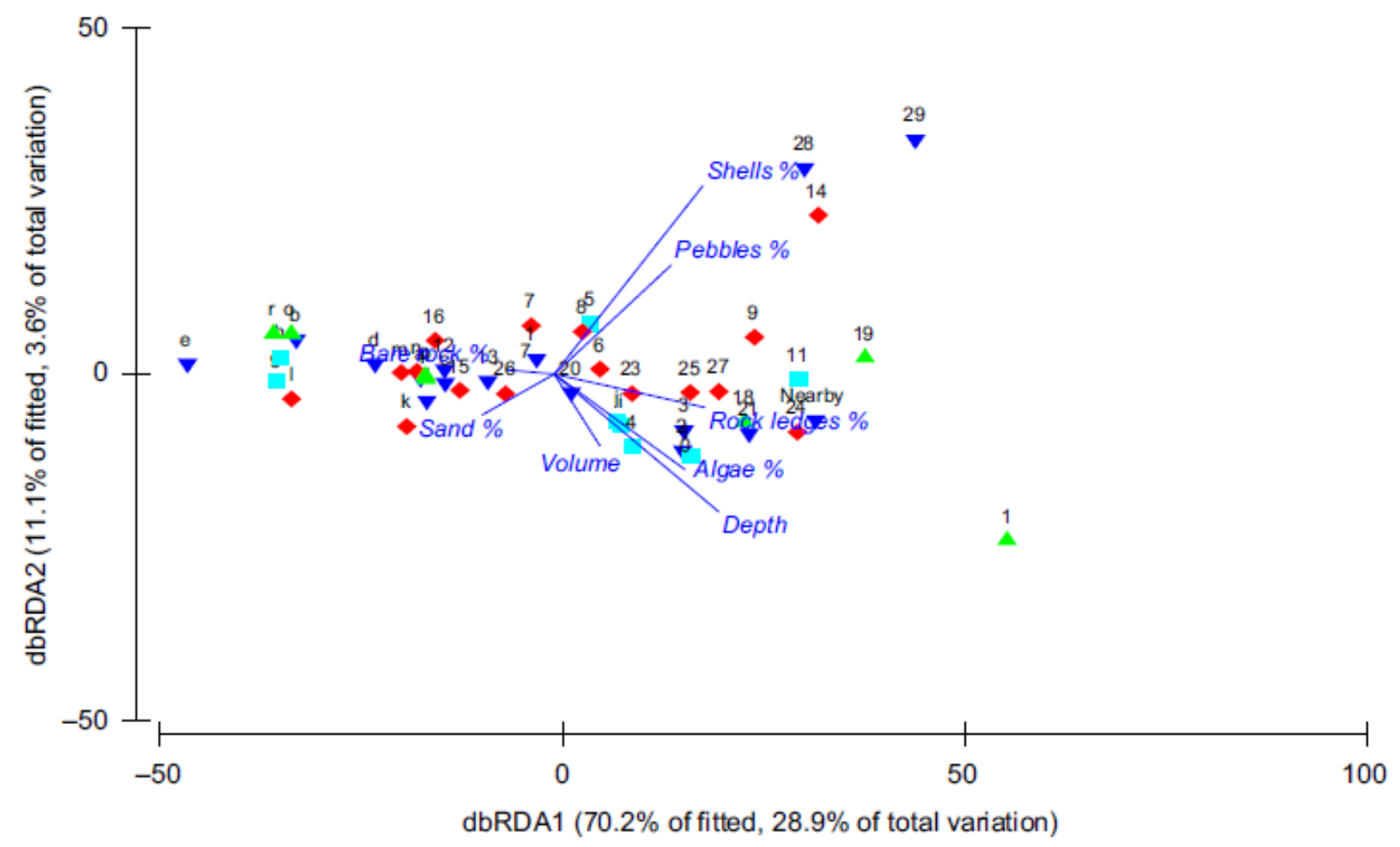

Fig. 3. Distance based redundancy analysis (dbRDA) ordination plot displaying the relationship between rock pool characteristics that best explain the variation of fish assemblages among pools at different sites. Symbols reflect rock pool locations: ( $\triangle$ ) Balmoral beach, ( $\nabla)$ Chowder Bay, ( $\square$ ) Dee Why beach, and ( $\bullet)$ Freshwater beach. Numbers refer to rock pool identification numbers. The vector lines within the circle show the 'effect' of the rock pool characteristic variables on fish abundance, the longer the line the more important the variable is in influencing the abundance of fish. Line direction shows how different the values are.

There are many different ecological and physical characteristics that determine the structure and distribution of fish assemblages in rock pools (Gibson 1982; Zander et al. 1999). The difficulty, however, lies in determining the specific contribution of each characteristic. For the fish assemblages analysed in the present study, rock-pool depth and structural complexity appear to be more important than pool volume in determining fish presence. Deep pools with loose shells and rocks, algal cover and overhanging rock ledges generally had higher fish diversity and abundance than small, shallow pools with little or no cover. Most often fish were found under some form of cover in deep, well-shaded pockets.

Although overall fish abundance did not vary in response to the vertical position of the rock pool on the rocky shore, there were differences in assemblage composition. Many species were only found in one particular tidal range, while others were apparently unaffected by this factor which is consistent with other studies (Nakamura 1976; Richkus 1978; Wells 1986). Rock pools occurring on the upper edge of the inter-tidal zone are generally exposed to atmospheric and terrestrial influences for greater periods of time than pools further down on the shore. In the present study, this zone was dominated by residents, which spend their entire life (juvenile to adult) within the inter-tidal zone, and are physiologically, morphologically 
Table 2. Fish species caught in 48 rock pools from four locations in Sydney, NSW, in order of decreasing family abundance. Each species is categorized into family, residency status and location of capture. Total number of each species caught is shown. Maximum size is based on published records.

\begin{tabular}{|c|c|c|c|c|c|c|c|c|}
\hline family & species & common name & $\begin{array}{l}\text { number } \\
\text { collected }\end{array}$ & $\begin{array}{l}\text { residency } \\
\text { status }\end{array}$ & $\begin{array}{l}\text { size } \\
\text { range } \\
\text { collected } \\
(\mathrm{mm})\end{array}$ & $\begin{array}{l}\max \\
\text { size } \\
(\mathrm{mm})\end{array}$ & Iocation & rock pool \\
\hline Gobiidae & $\begin{array}{l}\text { Bathygobius cocosensis } \\
\text { (Bleeker, 1854) }\end{array}$ & Cocos frillgoby & 391 & $\mathrm{R}$ & $16-60$ & 100 & $\mathrm{~B}, \mathrm{C}, \mathrm{D}, \mathrm{F}$ & $\begin{array}{l}1,3,4,5,6,7,8,9,10 \\
12,13,14,16,17,18,19 \\
20,22,23,24,25,28,29\end{array}$ \\
\hline Gobiidae & $\begin{array}{l}\text { Bathygobius krefftii } \\
\text { (Steindachner, 1866) }\end{array}$ & Krefft's frillgoby & 36 & $\mathrm{R}$ & $24-55$ & 90 & $B, C$ & $18,19,21$ \\
\hline Gobiidae & Pseudogobius sp. 9 & Blue-spot goby & 9 & $\mathrm{R}$ & $20-36$ & 76 & $\mathrm{D}$ & 5 \\
\hline Gobiidae & $\begin{array}{l}\text { Callogobius depressus } \\
\text { (Ramsay \& Ogilby, 1886) }\end{array}$ & Flathead goby & 4 & $\mathrm{R}$ & $28-65$ & 140 & $\mathrm{~B}, \mathrm{C}$ & $3,18,19$ \\
\hline Gobiidae & $\begin{array}{l}\text { Cryptocentroides gobioides } \\
\text { (Ogilby, 1886) }\end{array}$ & $\begin{array}{l}\text { Crested oyster } \\
\text { goby }\end{array}$ & 5 & $\mathrm{R}$ & $50-101$ & 100 & $B, D$ & 5,18 \\
\hline Scorpaenidae & $\begin{array}{l}\text { Centropogon australis } \\
\text { (White, 1790) }\end{array}$ & Fortescue & 152 & SR & $13-65$ & 140 & $\mathrm{~B}, \mathrm{C}, \mathrm{D}, \mathrm{F}$ & $3,4,5,18,19,22,23$ \\
\hline Tripterygiidae & $\begin{array}{l}\text { Enneapterygius atrogulare } \\
\text { (Gunther, 1873) }\end{array}$ & $\begin{array}{l}\text { Ringscale } \\
\text { triplefin }\end{array}$ & 145 & $\mathrm{R}$ & $19-52$ & 50 & $\mathrm{~B}, \mathrm{C}, \mathrm{F}$ & $\begin{array}{l}3,17,18,19,20,23,24 \\
25\end{array}$ \\
\hline Tripterygiidae & $\begin{array}{l}\text { Lepidoblennius } \\
\text { haplodactylus } \\
\text { (Steindachner, 1867) }\end{array}$ & $\begin{array}{l}\text { Eastern jumping } \\
\text { blenny }\end{array}$ & 103 & $\mathrm{R}$ & $25-119$ & 120 & $\mathrm{~B}, \mathrm{C}, \mathrm{F}$ & $\begin{array}{l}2,3,14,16,17,18,19 \\
20,23,26,27\end{array}$ \\
\hline Microcanthidae & $\begin{array}{l}\text { Microcanthus strigatus } \\
\text { (Cuvier, 1831) }\end{array}$ & Stripey & 83 & SR & $13-54$ & 160 & $\mathrm{~B}, \mathrm{C}, \mathrm{D}$ & $4,5,19,20,22$ \\
\hline Atherinidae & $\begin{array}{l}\text { Atherinomorus lacunosus } \\
\text { (Forster 1801) }\end{array}$ & $\begin{array}{l}\text { Slender } \\
\text { hardyhead }\end{array}$ & 61 & $\mathrm{~T}$ & $12-30$ & 250 & $B, D$ & $1,19,22$ \\
\hline Atherinidae & $\begin{array}{l}\text { Atherinomorus vaigiensis } \\
\text { (Quoy and Gaimard, 1825) }\end{array}$ & $\begin{array}{l}\text { Common } \\
\text { hardyhead }\end{array}$ & 7 & $\mathrm{~T}$ & $14-34$ & 170 & B & 1 \\
\hline Ambassidae & $\begin{array}{l}\text { Ambassis marianus } \\
\text { (Günther, 1880) }\end{array}$ & $\begin{array}{l}\text { Ramsey's } \\
\text { glassfish }\end{array}$ & 56 & SR & $9-21$ & 100 & $\mathrm{D}$ & $4,5,22$ \\
\hline Mullidae & $\begin{array}{l}\text { Parupeneus spilurus } \\
\text { (Bleeker, 1854) }\end{array}$ & $\begin{array}{l}\text { Blacksaddle } \\
\text { goatfish }\end{array}$ & 35 & $\mathrm{~T}$ & $70-108$ & 470 & $B, D$ & 1,22 \\
\hline Mugilidae & $\begin{array}{l}\text { Myxus elongatus (Günther } \\
\text { 1861) }\end{array}$ & Sand mullet & 30 & SR & $45-79$ & 400 & $\mathrm{D}$ & 22 \\
\hline Pomacentrinae & $\begin{array}{l}\text { Abudefduf vaigiensis } \\
\text { (Linnaeus, 1758) }\end{array}$ & $\begin{array}{l}\text { Indo-Pacific } \\
\text { sergeant }\end{array}$ & 18 & SR & $20-48$ & 229 & $\mathrm{~B}, \mathrm{C}, \mathrm{D}, \mathrm{F}$ & $4,18,20,22,23$ \\
\hline Clinidae & $\begin{array}{l}\text { Heteroclinus fasciatus } \\
\text { (Macleay, 1881) }\end{array}$ & $\begin{array}{l}\text { Banded } \\
\text { weedfish }\end{array}$ & 14 & $\mathrm{R}$ & $26-38$ & 65 & $\mathrm{~B}, \mathrm{C}$ & 3,18 \\
\hline Clinidae & $\begin{array}{l}\text { Heteroclinus whiteleggii } \\
\text { (Ogilby, 1894) }\end{array}$ & $\begin{array}{l}\text { Whitelegg's } \\
\text { weedfish }\end{array}$ & 13 & $\mathrm{R}$ & $28-41$ & 100 & $\mathrm{~B}, \mathrm{C}$ & 18,20 \\
\hline Blenniidae & $\begin{array}{l}\text { Parablennius intermedius } \\
\text { (Ogilby, 1915) }\end{array}$ & Horned blenny & 14 & $\mathrm{R}$ & $44-59$ & 120 & $\mathrm{~B}, \mathrm{C}, \mathrm{F}$ & $17,18,23,24,28$ \\
\hline Blenniidae & $\begin{array}{l}\text { Istiblennius meleagris } \\
\text { (Valenciennes, 1836) }\end{array}$ & $\begin{array}{l}\text { Peacock } \\
\text { rockskipper }\end{array}$ & 2 & $\mathrm{R}$ & $44-56$ & 150 & B & 18 \\
\hline Terapontidae & $\begin{array}{l}\text { Terapon jarbua (Forssk_al, } \\
\text { 1775) }\end{array}$ & Crescent perch & 14 & $\mathrm{SR}$ & $75-110$ & 250 & $C, D$ & $4,20,22$ \\
\hline Terapontidae & $\begin{array}{l}\text { Pelates sexlineatus (Quoy } \\
\text { \& Gaimard, 1824) }\end{array}$ & $\begin{array}{l}\text { Eastern striped } \\
\text { grunter }\end{array}$ & 1 & $\mathrm{~T}$ & 48 & 200 & $\mathrm{C}$ & 20 \\
\hline Kyphosidae & $\begin{array}{l}\text { Girella elevata (Macleay } \\
\text { 1881) }\end{array}$ & Black drummer & 10 & SR & $80-100$ & 600 & $\mathrm{C}, \mathrm{F}$ & $3,20,23,25,28$ \\
\hline Lutjanidae & $\begin{array}{l}\text { Lutjanus fulviflamma } \\
\text { (Forsskål, 1775) }\end{array}$ & Dory snapper & 8 & $\mathrm{~T}$ & $61-98$ & 350 & $\mathrm{D}$ & 4,22 \\
\hline Tetraodontidae & $\begin{array}{l}\text { Tetractenos glaber } \\
\text { (Fréminville, 1813) }\end{array}$ & Smooth toadfish & 8 & $\mathrm{~T}$ & $56-89$ & 150 & $\mathrm{D}$ & 22 \\
\hline Tetraodontidae & $\begin{array}{l}\text { Tetractenos hamiltoni (Gray } \\
\text { \& Richardson, 1843) }\end{array}$ & $\begin{array}{l}\text { Common } \\
\text { toadfish }\end{array}$ & 5 & $\mathrm{~T}$ & $59-87$ & 130 & $\mathrm{D}$ & 22 \\
\hline Gobiesocidae & $\begin{array}{l}\text { Aspasmogaster costata } \\
\text { (Ogilby, 1885) }\end{array}$ & Pink clingfish & 3 & $\mathrm{R}$ & $28-35$ & 50 & C & 3 \\
\hline Muraenidae & $\begin{array}{l}\text { Gymnothorax prasinus } \\
\text { (Richardson, 1848) }\end{array}$ & Green moray & 1 & $\mathrm{R}$ & 500 & 1000 & C & 17 \\
\hline
\end{tabular}


and behaviorally adapted to cope with the drastic physicochemical changes occurring within these rock pools (i.e. fluctuating temperature, salinity and oxygen levels). Resident families such as Gobiidae, Blenniidae and Tripterygiidae were very common in this upper zone; this is probably because predators and interspecific competitors cannot withstand the physiochemical changes occurring at this level of the shore and therefore there is a lower risk of predation and more resources are available. The two secondary resident species found in rock pools at high vertical positions in this study were never larger than $2 \mathrm{~cm}$, so it may be that at this small size they are better able to tolerate the fluctuating conditions. A number of studies have observed that smaller fishes are generally more abundant higher up on the intertidal zone (Nakamura 1976; Milton 1983; Prochazka \& Griffiths 1992).

The mid inter-tidal zone (5-10 $\mathrm{m}$ from water's edge) is affected by atmospheric and terrestrial influences to a lesser extent, than the upper inter-tidal zone which means that even smaller rock pools will offer less extreme habitats than those positioned higher on the rock platform (Macieira \& Joyeux 2011). Accordingly, we found that secondary residents and transient species with few/no adaptations to life in the inter-tidal zone were more likely to be found here than in the higher zone. Furthermore, differences in fish assemblage structure between rock pools in this middle zone can be more directly related to the structural complexity of the habitat because it regulates the number of niches that are available (i.e. greater percentage of rock ledges, algal cover, loose rocks and shells).

Table 3. Relationship between rock-pool characteristics and species abundances (step-wise regression results). Variables are listed in order of addition in the forward selection model. Only rock-pool characteristics that had a significant effect on species abundances are displayed in the table.

\begin{tabular}{|lllll|}
\hline species & characteristic & $\mathbf{R}^{2}$ value & F-value & P-value \\
\hline Ambassis marianus & Volume & 0.803 & 188.094 & $<0.0001$ \\
& Depth & 0.822 & 104.166 & $<0.0001$ \\
Atherinomorus lacunosus & Volume & 0.930 & 614.836 & $<0.0001$ \\
Bathygobius cocosensis & Volume & 0.507 & 47.384 & $<0.0001$ \\
& Rock ledges \% & 0.558 & 28.424 & $<0.0001$ \\
Bathygobius krefftii & Shells \% & 0.804 & 188.228 & $<0.0001$ \\
Centropogon australis & Volume & 0.255 & 15.723 & 0.0003 \\
Enneapterygius atrogulare & No. algae species & 0.289 & 18.668 & $<0.0001$ \\
& Volume & 0.404 & 15.283 & $<0.0001$ \\
Heteroclinus fasciatus & Depth & 0.125 & 6.556 & 0.0138 \\
Heteroclinus whiteleggii & Depth & 0.094 & 4.794 & 0.0337 \\
Lepidoblennius haplodactylu & No. algae species & 0.097 & 4.932 & 0.0313 \\
Microcanthus strigatus & Depth & 0.108 & 5.562 & 0.0227 \\
Parablennius intermedius & No. algae species & 0.088 & 4.421 & 0.0410 \\
Parupeneus spilurus & Volume & 0.835 & 233.322 & $<0.0001$ \\
Terapon jarbua & Rock ledges \% & 0.852 & 129.922 & $<0.0001$ \\
\hline
\end{tabular}

The lowest zone (low inter-tidal), closest to the sea, contains many rock pools that remain connected to the sea or to other rock pools at low tide via cave systems, which permits greater water circulation to occur and makes physiochemical conditions within these rock pools almost identical to those within the sea (Gibson \& Yoshiyama 1999). In the present study, large rock pools in this zone had a greater number of species and also a greater number of juvenile and sub-adult secondary and transient species than the 
other zones, probably because many of these species are active swimmers that school. It should be noted that resident species made use of all three zones; however, they were found in greater numbers in the upper and middle zones.

The proportion of residents, secondary residents and transients within rock pools has been observed to change seasonally. For example, in most subtropical regions, such as Australia and North New Zealand, species abundances and total fish numbers are usually highest in the spring months, largely caused by the arrival of juvenile (residents, secondary residents and transients) following the breeding season (Willis \& Roberts 1996). The data in this study were collected between late winter and early summer so it is possible that the fish assemblage structure within the observed areas may differ completely during the summer and fall months (i.e. number of secondary residents and transients will likely drop dramatically). In Australia, the conditions within rock pools are most likely to be least accommodating during the hot summer, when temperatures rise dramatically during the day and oxygen concentrations drop accordingly. This contrasts with many studies conducted at higher latitudes where low winter temperatures is a key limiting factor to fish presence within the rock pools (Moring 1990).

Overall, it appears that resident, secondary resident and transient species all contribute significantly to assemblage structure but the extent to which they do so is likely to vary both geographically and seasonally (Gibson \& Yoshiyama 1999).

\section{Rock-pool characteristics determine species composition}

It appears that certain characteristics of home pools, such as pool volume, rock ledge availability, algal cover and predator presence may play a major role in determining which pool a species chooses to occupy by indicating high quality locations. All inter-tidal fish observed in this study displayed some form of microhabitat selectivity. Furthermore, many of these fishes are known to occupy the same pool for long periods of time (White \& Brown 2013) and thus they probably display very strong habitat selection.

Volume of home rock pools played a major role in determining which species inhabited the pools: seven out of the 13 species were more likely to be found in rock pools with larger volumes. Non-cryptically colored secondary residents (Centropogon australis, Microcanthus strigatus and Terapon jarbua) and transients (Parupeneus spilurus, Atherinomorus lacunosus and Atherinomorus vaigiensis) were only found in deep pools with large volumes. Given the life history of these species it would make sense that they would prefer larger/deeper pools, particularly as their size increases. Furthermore, depth/volume may also act as an indicator of greater stability in water conditions (i.e. temperature, salinity and oxygen availability would not fluctuate as greatly in larger pools) and also offer greater safety from aerial predators. According to Mahon \& Mahon (1994), larger rock pools offer a greater abundance of resources and niches to inter-tidal organisms, and therefore can support a greater number of species, individuals and biomass. In the present study, there was a general trend for smaller secondary resident and transient fish such as $A$. lacunosus and $M$. strigatus to be found in large pools, where they schooled at the waters surface or near algal and rock ledge cover; schooling behaviors create demands for a large amount of space (Lawson et al. 1999).

Availability of rock ledges and of algal cover appear to be very important in determining the abundance and distribution of inter-tidal fish (Mollick 1968; Nakamura 1976; Richkus 1978; Barton 1982). The majority of fish caught in this study were found in pools with some form of rock ledge cover and were only found in pools with no rock ledge cover if the pools contained loose pebbles, shells or some form of algal cover. For example, the habitat choice of Bathygobius cocosensis and Parupeneus spilurus was correlated to pools with greater rock ledge availability. This may be linked to predator avoidance behavior; for example, the transient species Paru spilurus was observed darting under the cover of rock ledges 
when approached by observers or aerial predators. By contrast, the resident species Enneapterygius atrogulare, Lepidoblennius haplodactylus and Parablennius intermedius were most often found in pools with a large variety of algae species, in particular rock pools containing pink coralline algae (Corallina offocinalis) and brown algae (Ecklonia radiata and Sargassum sp.), perhaps because their coloration is so similar to that of these algal species (red/pink to brown with banded or mottled patterning).

Some species were found in a variety of habitats, perhaps because they have an ability to camouflage against a wide range of backgrounds. Bathygobius cocosensis, for example, was the most commonly occurring species in this study and was found in pools of all descriptions. Individuals of this species can change their coloration from creamy white to dark brown with scattered dark and light blotches, allowing them to camouflage themselves against a wide range of surroundings (i.e. pebbles, rock ledges, coralline algae or sandy substrates).

In the present study, the presence of predators such as octopus, shore crabs or eels in home pools only correlated with the presence of three species. Bathygobius cocosensis was significantly more likely to be present in rock pools with only one type of predator present, most often shore crabs. By contrast, $E$. atrogulare and $L$. haplodactylus were significantly more likely to be present in rock pools with two types of predator present, most often a mixture of shore crabs and octopus. All three species are residents and so are likely to avoid being captured by predators through their cryptic coloration and familiarity with their immediate surroundings, allowing them to swiftly enter crevices and holes that are too narrow for predators to follow (Gibson 1982; Silberschneider \& Booth 2001). The pools containing predators also happened to be the deepest and had the greatest volumes so it may be that both the fishes and predators take advantage of these characteristics. Furthermore, we only collected data on the presence and absence of predators so it may be that in some cases very few predators were present in the pool and so presented no great threat to these species. Conducting a more detailed predator census would provide a more accurate account of the effect of predator presence on fish species abundance; the effects of aerial predator presence should also be documented.

While it appears that structurally complex rock-pool habitats play a major role in supporting greater species richness, it should also be recognized that habitats of all types, regardless of their overall structural complexity play a valuable role in preserving local fish diversity. This is due to the fact that some fishes are habitat specialists (Lieske \& Myers 2001; Kirsch et al. 2002) and others utilize different habitats during different stages of their development (Sedberry \& Carter 1993; Nagelkerken et al. 2000, 2001). Future experiments on rock-pool fish assemblages in the Sydney region should focus on investigating the following: variations in diet among species; competition within and among species; whether or not species composition varies vertically across the shore; measuring within-pool physical conditions (i.e. temperature, salinity, oxygen availability etc.); determining species tolerance levels to the within-pool physical conditions; and the effects of various levels of human access on rock-pool fish assemblages.

In conclusion, it is clear that high availability of cover (i.e. rock ledges, caves, crevasses, loose rocks or algal growth) is likely to be representative of good habitat and fish are therefore more likely to inhabit pools with these characteristics. Experiments that involve the manipulation of rock-pool substrate characteristics, such as those performed by Arakaki \& Tokeshi (2010), Griffiths et al. (2006) and Rojas \& Ojeda (2010), would allow for a more accurate estimate of the role that each characteristic plays in controlling the structure and species composition of rock-pool communities in the Sydney region. 


\section{Acknowledgements}

Many thanks are due to Anthony C. Gill for help with fish identification, Pauline Brunet and Caroline Baille for assistance with fieldwork, the anonymous reviewers for comments on the manuscript and Macquarie University for providing the funds necessary to perform this study. Fish collections were conducted under NSW Fisheries Scientific Collection Permit number P08/0010-3.0. Experimental methods in this study conformed to the standards set by the Macquarie University Animal Ethics committee (ARA\# 2011/021).

\section{References}

Anderson M.J., Gorley R.N., Clarke K.R. (2008) PERMANOVA+ for PRIMER: Guide to Software and Statistical Methods. PRIMER-E, Plymouth, UK.

Arakaki S., Tokeshi M. (2010) Analysis of spatial niche structure in coexisting tidepool fishes: null models based on multi-scale experiments. Journal of Animal Ecology, 80, 137-147.

Barton M.G. (1982) Comparative distribution and habitat preferences of two species of stichaeoid fishes in Yaquina Bay, Oregon. Journal of Experimental Marine Biology and Ecology, 59, 77-87.

Beck M.W. (2000) Separating the elements of habitat structure: independent effects of habitat complexity and structural components on rocky intertidal gastropods. Journal of Experimental Marine Biology and Ecology, 249, 29-49.

Begon M., Harper J.L., Townsend C.R. (1986) Ecology: Individuals, Populations, and Communities. Sinauer Associates Inc., Boston: 97-104.

Behrents K.C. (1987) The influence of shelter availability on recruitment and early juvenile survivorship of Lythrypnus dalli Gilbert (Pisces: Gobiidae). Journal of Experimental Marine Biology and Ecology, 107, 45-59.

Bell J.D., Burchmore J.J., Pollard D.A. (1980) The food and feeding habits of the rock blackfish, Girella elevata Macleay (Pisces: Girellidae), from the Sydney region, New South Wales. The Australian Zoologist, 20, 231-405.

Bennett B.A., Griffiths C.L. (1984) Factors affecting the distribution, abundance and diversity of rock-pool fishes on the Cape Peninsula, South Africa. South African Journal of Zoology, 19, 97-104.

Clarke K.R., Green R.H. (1988) Statistical design and analysis for a 'biological effects' study. Marine Ecology Progress Series, 46, 213-226.

Congleton J.L. (1980) Observations on the responses of some southern California tidepool fishes to nocturnal hypoxic stress. Comparative Biochemical and Physiology Part A: Molecular \& Integrative Physiology, 66, 719-722.

Cox T.E., Baumgartner E., Philippoff J., Boyle K.S. (2011) Spatial and vertical patterns in the tidepool fish assemblage on the island of O'ahu. Environmental Biology of Fishes, 90, 329-342.

Cunha E.A., Carvalho R.A.A., Monteiro-Neto C., Moraes L.E.S., Araújo M.E. (2008) Comparative analysis of tidepool fish species composition on tropical coastal rocky reefs at State of Ceará, Brazil. Iheringia, Série Zoologia, Por, 98, 379-390.

Davidowitz G., Rosenzweig M.L. (1998) The latitudinal gradient of species diversity among North American grasshoppers (Acrididae) within a single habitat: a test of the spatial heterogeneity hypothesis. Journal of Biogeography, 25, 553-560.

Davis J.L.D. (2000) Spatial and seasonal patterns of habitat partitioning in a guild of southern California tidepool fishes. Marine Ecology Progress Series, 196, 253-268.

Diamond J., Case T.J. (1986) Community Ecology. Harper \& Row, New York: 665 pp.

Firth L.B., Williams G.A. (2009) The influence of multiple environmental stressors on the limpet Cellana toreuma during the summer monsoon season in Hong Kong. Journal of Experimental Marine Biology and Ecology, 375, 70-75. 
Firth L.B., Thompson R.C., White F.J., Schofield M., Skov M.W., Hoggart S.P.G., Jackson J., Knights A.M., Hawkins S.J. (2013) The importance of water retaining features for biodiversity on artificial intertidal coastal defense structures. Diversity \& Distributions, 19, 1275-1283.

Gibson R.N. (1974) The vertical distribution and feeding relationships of intertidal fish on the Atlantic coast of France. Journal of Animal Ecology, 41, 189-207.

Gibson R.N. (1982) Recent studies on the biology of intertidal fishes. Oceanography and Marine Biology: An Annual Review, 20, 363-414.

Gibson R.N., Yoshiyama R.M. (1999) Intertidal fish communities. In: Horn M.H., Martin K.L.M., Chotkowski M.A. (Eds), Intertidal Fishes: Life in Two Worlds. Academic Press, San Diego: 264296.

Gratewicke B., Speight M.R. (2005) The relationship between fish species richness, abundance and habitat complexity in a range of shallow tropical marine habitats. Journal of Fish Biology, 66, 650667.

Griffiths S.P. (2003) Rockpool ichthyofaunas of temperate Australia: species composition, residency and biogeographic patterns. Estuarine, Coastal and Shelf Science, 58, 173-186.

Griffiths S.P., West R.J., Davis A.R. (2003) Effects of intertidal elevation on the rockpool ichthyofaunas of temperate Australia. Environmental Biology of Fishes, 68, 197-204.

Griffiths S.P., Davis A.R., West R.J. (2006) Role of habitat complexity in structuring temperate rockpool ichthyofaunas. Marine Ecology Progress Series, 313, 227-239.

Hixon M.A., Beets J.P. (1993) Predation, prey refuges, and the structure of coral-reef fish assemblages. Ecological Monographs, 63, 77-101.

Horn M.H., Martin K.L.M., Chotkowski M.A. (1999) Introduction. In: Horn M.H., Martin K.L.M., Chotkowski M.A. (Eds), Intertidal Fishes: Life in Two Worlds. Academic Press, San Diego: 1-6.

Jensen S.L., Muller-Parker G. (1994) Inorganic nutrient fluxes in anemone-dominated tide pools. Pacific Science, 48, 32-43.

Jones G.P. (1984) The influence of habitat and behavioural inter-actions on the local distribution of the wrasse, Pseudolabrus celidotus. Environmental Biology of Fishes, 10, 43-58.

Kemp J.O.G. (2009) Effects of temperature and salinity on resting metabolism in two South African rock pool fish: the resident gobiid Caffrogobius caffer and the transient sparid Diplodus sargus capensis. African Zoology, 44, 151-158.

Kirsch K.D., Valentine J.F., Heck K.L. Jr (2002) Parrotfish grazing on turtlegrass Thalassia testudinum: evidence for the importance of seagrass consumption in food web dynamics of the Florida Keys National Marine Sanctuary. Marine Ecology Progress Series, 227, 71-85.

Lardner R., Ivantsoff W., Crowley L.E.L.M. (1993) Recolonization by fishes of a rocky intertidal pool following repeated defaunation. The Australian Zoologist, 29, 85-92.

Lawson G.L., Kramer D.L., Hunte W. (1999) Size-related habitat and schooling behavior in two species of surgeonfish (Acanthurus bahianus and $A$. coeruleus) on a fringing reef in Barbados, West Indies. Environmental Biology of Fishes, 54, 19-33.

Lieske E., Myers R. (2001) Collins Pocket Guide: Coral Reef Fishes. Collins, London: 420 pp.

Macieira R.M., Joyeux J.C. (2011) Distribution patterns of tidepool fishes on a tropical flat reef. Fishery Bulletin, 109, 305-315.

Mahon R., Mahon S.D. (1994) Structure and resilience of a tidepool fish assemblage at Barbados. Environmental Biology of Fishes, 41, 171-190.

Marsh B., Crowe T.M., Siegfried W.W. (1978) Species richness and abundance of Clinid fish (Teleostei: Clinidae) in intertidal rock pools. South African Journal of Zoology, 13, 283-291.

Martins G.M., Hawkins S.J., Thompson R.C., Jenkins S.R. (2007) Community structure and functioning in intertidal rock pools: effects of pool size and shore height at different successional stages. Marine Ecology Progress Series, 329, 43-55. 
Metaxas A., Scheibling R.E. (1993) Community structure and organization of tidepools. Marine Ecology Progress Series, 98, 187-198.

Milton P. (1983) Biology of littoral blenniid fishes on the coast of southwest England. Journal of the Marine Biological Association of the United Kingdom, 63, 223-237.

Mollick R.S. (1968) The distribution of Clinocottus analis Girard in tide pools as related to substrate prefernce M.A. thesis, California State University, San Diego.

Moring J.R. (1990) Seasonal absence of fishes in tidepools of a boreal environment (Maine, USA). Hydrobiologia, 194, 163-168.

Nagelkerken I., Dorenbosch M., Verberk W.C.E.P., Cocheret de la Moriniere E., van der Velde G. (2000) Importance of shallow-water biotopes of a Caribbean bay for juvenile coral reef fishes: patterns in biotope association and spatial distribution. Marine Ecology Progress Series, 202, 175-192.

Nagelkerken I., Kleijnen S., Klop T., van den Brand R.A.C.J., Cocheret de la Moriniere E., van der Velde G. (2001) Dependence of Caribbean reef fishes on mangroves and seagrass beds as nursery habitats: a comparison of fish faunas between bays with and without mangroves/seagrass beds. Marine Ecology Progress Series, 214, 225-235.

Nakamura R. (1976) Experimental assessment of factors influencing microhabitat selection by the two tidepool fishes Oligocottus maculosus and O. snyderi. Marine Biology, 37, 97-104.

Paine R.T. (1974) Intertidal community structure, experimental studies on the relationship between a dominant competitor and principal predator. Oecologia, 15, 93-120.

Pianka E.R. (1973) The structure of lizard communities. Annual Review of Ecology and Systematics, 4, 53-74.

Prochazka K., Griffiths C.L. (1992) The intertidal fish fauna of the west coast of South Africa-Species, community and biogeographic patterns. South African Journal of Zoology, 27, 11.5-120.

Richkus W.A. (1978) A quantitative study of intertidepool movement of the woolly sculpin, Clinocottus analis. Marine Biology, 49, 277-284.

Rojas J.M., Ojeda F.P. (2010) Spatial distribution of intertidal fishes: a pattern dependent on body size and predation risk? Environmental Biology of Fishes, 87, 175-185.

Sedberry G.R., Carter J. (1993) The fish community of a shallow tropical lagoon in Belize, Central America. Estuaries, 16, 198-215.

Silberschneider V., Booth D.J. (2001) Resource use by Enneapterygius rufopileus and other rockpool fishes. Environmental Biology of Fishes, 61, 195-204.

Telleria J.L., Carrascal L.M. (1994) Weight-density relationships between and within bird communities: implications of niche space and vegetation structure. The American Naturalist, 143, 1083-1092.

Tsering L., Pawar H.B., Sreepada R.A., Sanaye S.V., Suryavanshi U., Tanu. (2012) Ichthyofaunal diversity and ecology of intertidal rock pools of Goa, west coast of India. Fishing Chimes, 32, 5659.

Underwood A.J., Skilleter G.A. (1996) Effects of patch-size on the structure of assemblages in rock pools. Journal of Experimental Marine Biology and Ecology, 197, 63-90.

Wells A.W. (1986) Aspects of ecology and life history of the woolly sculpin, Clinocottus analis, from southern California. California Fish and Game, 72, 213-226.

White G.E., Brown C. (2013) Site fidelity and homing behavior in intertidal fishes. Marine Biology, 160, 1365-1372.

Williams G.A., Morritt D. (1995) Habitat partitioning and thermal tolerance in a tropical limpet, Cellana grata. Marine Ecology Progress Series, 124, 89-103.

Williams S.E., Marsh H., Winter J. (2002) Spatial scale, species diversity, and habitat structure: small mammals in Australian tropical rain forest. Ecology, 83, 1317-1329.

Willis T.J., Roberts C.D. (1996) Recolonisation and recruitment of fishes to intertidal rockpools at Wellington, New Zealand. Environmental Biology of Fishes, 47, 329-343. 
Wilson G.G.(1989). Patterns of recruitment and rock-pool recolonisation in a rocky intertidal fish community: effects of habitat heterogeneity. BSc (Hons) thesis. University of New England, Armadale, NSW.

Zander C.D., Nieder J., Martin K. (1999) Vertical distribution patterns. In: Horn M.H., Martin K.L.M., Chotkowski M.A. (Eds), Intertidal Fishes: Life in Two Worlds. Academic Press, USA: 26-53. 